\title{
Tantangan Implementasi Manajemen Proyek Teknologi Informasi Dalam Masa Pandemi Covid-19
}

\author{
Dani Pradana ${ }^{1}$ \\ ${ }^{1}$ STMIK BANDUNG \\ Sekolah Tinggi Manajemen Informatika dan Komputer Bandung Jl.Cikutra \\ No.113A, Bandung 40124, INDONESIA \\ Contact address : 022-7207777 \\ 1dani.pradana@stmik-bandung.ac.id
}

\begin{abstract}
Intisari- Proyek adalah sebuah kegiatan yang bersifat sementara yang telah ditetapkan awal pekerjaan dan waktu selesainya (biasanya selalu dibatasi oleh waktu, seringkali juga dibatasi oleh sumber pendanaan), untuk mencapai tujuan dan hasil yang spesifik dan unik, serta pada umumnya untuk menghasilkan sebuah perubahan yang bermanfaat atau yang mempunyai nilai tambah. Dalam situasi yang sangat kompetitif saat ini dan kondisi masa pandemi Covid-19, manajemen proyek sudah menjadi suatu keahlian yang paling bernilai di semua jenis perusahaan. Untuk mencapai keberhasilan dan kesuksesan, perlu kiranya bagi perusahaan untuk menjalankan proyek tepat waktu, sesuai ruang lingkup kerja, efisiensi biaya, dan kualitas yang baik. Pada penelitian ini akan ditinjau tentang beberapa hal yang terkait dengan tantangan implementasi manajemen proyek teknologi informasi yang ditinjau dari faktor-faktor yang mempengaruhi kegagalan implementasi proyek tersebut.
\end{abstract}

Kata kunci- Proyek, Manajemen proyek, Pandemi Covid-19, Keberhasilan dan kesuksesan proyek, Faktor kegagalan proyek.

Abstract - A project is an activity that is temporary in nature which has been assigned the initial work and completion time (usually always limited by time, often also limited by funding sources), to achieve specific and unique goals and results, and generally to produce a useful change or which has added value. In the current very competitive situation and the conditions during the Covid-19 pandemic, project management has become the most valuable skill for all types of companies. To achieve success and success, it is necessary for companies to carry out projects on time, according to the scope of work, cost efficiency, and good quality. This research will review several things related to the challenges of implementing information technology project management in terms of the factors that influence the failure of the project implementation.

Keywords - Project, Project management, Covid-19 Pandemic, Project success, Project failure factors.

\section{Pendahuluan}

Berdasarkan definisi dari A Guide to the Project Management Body of Knowledge (PMBOK) edisi ke-6 (PMI, 2017) [5], definisi proyek adalah suatu usaha sementara yang dilakukan untuk menghasilkan suatu produk atau jasa yang unik :

a. Sementara artinya setiap proyek memiliki tanggal mulai dan selesai tertentu.

b. Unik artinya produk atau jasa yang dihasilkan adalah berbeda dari yang lainnya.

Dengan kata lain, setiap proyek harus memiliki awal dan akhir yang jelas, memiliki sekumpulan aktivitas yang berurutan, dan memiliki sasaran tertentu (Heryanto, 2016) [2]. Manajemen proyek adalah aplikasi atau implementasi dari pengetahun, ketrampilan, perangkat, dan teknis pada suatu aktivitas proyek untuk memenuhi kebutuhan dan tujuan suatu proyek (Heryanto, 2016) [2].

Faktor pembatas dalam lingkup manajemen proyek diantaranya yaitu ruang lingkup, waktu, dan biaya (scope, schedule, dan cost). Masing-masing faktor pembatas tersebut dijelaskan seperti di bawah ini (Heryanto, 2016) [2].

Pada ruang lingkup dibahas mengenai jenis dan sejauh mana batasan yang ada pada sebuah proyek ditentukan. Ruang lingkup sangat diperlukan pada suatu proyek, karena hal ini akan memberi dampak pada faktor proyek lainnya, terutama yang menyangkut biaya dan waktu pengerjaan proyek. Semakin besar ruang lingkup, maka secara umum akan makin bertambah waktu pengerjaan dan biaya yang harus dikeluarkan.

Waktu adalah suatu komponen yang menjadi target utama dalam suatu proyek, bagaimana kita menentukan lamanya waktu yang diperlukan untuk menyelesaikan sebuah proyek. Komponen waktu sangat berarti, terutama pada saat aktivitas yang memang krusial. Terkadang suatu proyek dipaksa untuk selesai pada waktu tertentu, walaupun berdampak pada membengkaknya biaya.

Biaya adalah suatau faktor atau komponen utama proyek yang menentukan seberapa besar biaya yang akan dikeluarkan untuk sebuah proyek. Faktor biaya sangat dipengaruhi oleh faktor ruang lingkup dan waktu. Secara umum, semakin besar 
ruang lingkup dan lama waktu, maka akan semakin besar pula biaya suatu proyek.

Optimasi triple constraints (scope, schedule, dan cost) sangat diperlukan untuk mencapai keseimbangan dalam mencapai sebuah target. Untuk mencapai kualitas dari suatu target tertentu, maka optimasi ketiga komponen tersebut sangat diperlukan. Jika triple constraints ditambah dengan kualitas (quality), maka akan lebih baik proses optimasinya (Heryanto, 2016) [2].

Manajemen proyek perangkat teknologi informasi dimulai dengan serangkaian kegiatan yang secara kolektif, disebut perencanaan proyek. Sebelum proyek dapat dimulai, tim perangkat teknologi informasi harus memperkirakan pekerjaan yang perlu dilakukan, sumber daya yang akan diperlukan, dan waktu yang akan dibutuhkan dari awal sampai akhir. Pada suatu jenis proyek tertentu, sumber daya dapat dikelompokkan menjadi sumber daya, mesin, material, uang, dan metode (manpower, machine, material, money, dan method) [3].

Suatu kebutuhan nyata untuk perangkat teknologi informasi telah ditetapkan; pemangku kepentingan (stakeholder) sudah siap untuk mulai bekerja, dan proyek pun akan dimulai. Perencanan proyek perangkat teknologi informasi meliputi 5 aktivitas utama [4] :
a. Estimasi
b. Penjadwalan
c. Analisis risiko
d. Perencanaan manajemen kualitas
e. Perencanaan manajemen perubahan

\section{Metodologi Penelitian}

Dari 5 aktivitas utama yang tertera pada bagian pendahuluan, maka hanya akan ditinjau faktor tentang analisis risiko (Husen, 2011) [3], (Orr, 2004) [4].

A. Analisis Risiko

Tingkat ketidakpastian struktural juga berdampak pada risiko estimasi. Dalam hal ini, struktur mengacu pada tingkat ketika kebutuhan tetap dilengkapi dengan kemudahan yang membuat fungsi-fungsi dapat dipilah-pilah, dan sifat hirarki informasi yang harus diproses.

Ketersediaan informasi yang bersifat historis mempunyai pengaruh yang kuat pada risiko estimasi. Dengan melihat ke belakang, Manajer proyek dapat menirukan kesuksesan dan memperbaiki area yang memunculkan permasalahan. Ketika metrik perangkat teknologi informasi yang komprehensif tersedia pada proyek-proyek masa lalu, estimasi dapat dilakukan dengan jaminan yang lebih bagus, jadwal dapat dibentuk untuk menghindari kesulitan-kesulitan masa lalu, dan risiko secara keseluruhan akan berkurang.

\section{B. Manajemen Kegagalan dan Risiko Proyek}

Keberhasilan suatu proyek sangat bergantung pada saat menentukan pilihan metodologi manajemen proyek yang baik. Pemilihan metodologi ini dilakukan pada saat awal sebelum proyek mulai. Tidak ada jaminan pada proyek apapun, bahkan aktivitas yang paling sederhana dapat mengalami masalah tak terduga. Kapan saja ada sesuatu yang mungkin terjadi pada proyek dan akan mengubah hasil dari kegiatan proyek. Suatu proyek pasti mempunyai risiko, yang utama adalah kegagalan proyek, baik dalam mencapai tujuan ataupun memenuhi kriteria batasan proyek (ruang lingkup, waktu, biaya, kualitas). Bagaimana mengelola manajemen risiko sehingga proyek bisa diselesaikan sesuai dengan ruang lingkup dan jadwal yang telah ditentukan, anggaran biaya yang telah disepakati, serta kualitas yang memenuhi kriteria yang telah ditetapkan pada awal proyek.

\section{Faktor Kegagalan Proyek}

Hal-hal berikut ini harus diperhatikan agar proyek tidak dikategorikan gagal. Semakin besar dan kompleks suatu proyek akan semakin besar kemungkinan untuk gagal. Untuk menghindari kemungkinan gagal, berikut ini adalah beberapa faktor yang menyebabkan gagalnya atau dibatalkannya suatu proyek antara lain [8] :

1) Sistem atau metodologi manajemen proyek di perusahaan:

a. Belum adanya solusi formal untuk sistem atau metodologi manajemen proyek

b. Belum memahami nilai dari manajemen proyek

2) Project Management Office (PMO) :

a. Belum menggunakan praktek manajemen proyek yang sudah terstandarisasi

b. Belum bisa menetapkan atau memonitor ukuran kinerja keberhasilan proyek

c. Belum bisa melakukan manajemen alokasi sumber daya proyek, penyusunan anggota tim proyek yang tidak tepat, termasuk untuk menyediakan manajer proyek

3) Masalah yang terkait dengan kontribusi anggota tim proyek :

a. Kurangnya keselarasan dengan tim.

b. Kurangnya keterbukaan dalam komunikasi

c. Ketidakmampuan untuk menyelesaikan konflik

d. Kurangnya partisipasi dan kreativitas tim

e. Kepemimpinan yang tidak efektif, dalam hal ini manajer proyek yang tidak berpengalaman

f. Kurangnya penghargaan pada anggota tim proyek

4) Alur kerja otomatis untuk solusi manajemen proyek modern :

a. Belum adanya solusi formal untuk alur kerja otomatis

b. Belum memahami transformasi digital yang telah berkembang pesat sampai saat ini

5) Keterlibatan pemangku kepentingan (stakeholder) :

a. Kurangnya dukungan dari manajemen dan sponsor yang secara aktif mendukung pelaksanaan proyek

b. Belum menciptakan budaya yang menghargai manajemen proyek

c. Belum mengembangkan keterampilan implementasi 
strategi di kalangan pemangku kepentingan

6) Permintaan kebutuhan yang tidak direncanakan ( ad hoc requests).

a. Kebutuhan proyek yang tidak jelas dan sering mengalami perubahan yang tidak direncanakan

7) Tingkat kematangan yang mengarah ke kinerja proyek yang lebih besar

a. Proyek tidak selesai tepat waktu

b. Proyek yang diselesaikan tidak sesuai anggaran

c. Proyek yang diselesaikan tidak memenuhi standar kualitas yang sudah ditetapkan

d. Proyek yang diselesaikan sering mengalami perubahan kebutuhan dan spesifikasi

e. Belum bisa mempertahankan fokus pada manfaat, termasuk untuk melakukan transisi proyek yang telah selesai menuju ke bisnis

f. Belum melakukan investasi dalam teknologi untuk memungkinkan keberhasilan proyek dengan lebih baik

8) Investasi untuk memperluas keterampilan dalam manajemen proyek

a. Belum melakukan pelatihan tentang penggunaan alat dan teknik manajemen proyek

b. Belum memiliki proses formal untuk mengembangkan kompetensi manajer proyek

c. Belum memiliki jalur karir yang ditentukan untuk mereka yang terlibat dalam manajemen proyek

d. Belum memiliki proses formal untuk mentransfer pengetahuan dari satu bagian organisasi ke bagian lainnya

e. Kurang memprioritaskan pengembangan keterampilan teknis, profesional, kepemimpinan, dan bisnis manajemen proyek

9) Manajemen risiko proyek

a. Belum menerapkan manajemen risiko proyek, peluang dan risiko tidak ditentukan

b. Kurangnya ketersedian sumber daya proyek atau keterbatasan sumber daya proyek

c. Kurangnya niat untuk belajar dari kegagalan proyek sebelumnya

10) Manajemen perubahan proyek

a. Belum menerapkan manajemen perubahan proyek atau manajemen perubahan yang buruk

b. Adanya perubahan dalam prioritas perusahaan dan tujuan proyek, belum menciptakan budaya reseptif terhadap perubahan organisasi

c. Adanya perubahan yang tidak terkontrol pada ruang lingkup proyek

Untuk menangani risiko kegagalan proyek tersebut di atas, maka biasanya, berusaha menghindari risiko dapat menyebabkan pemborosan sumber daya. Anda juga dapat meminimalkan risiko yang mungkin terjadi, dengan mengalokasikan sumber daya lebih besar dan perhatian khusus terhadap risiko yang berdampak besar.

Jika analisa risiko dilakukan dengan baik, maka Anda dapat merencanakan antisipasi yang dapat meminimalisir dampak yang mungkin terjadi. Menerima risiko artinya proyek mempersiapkan diri untuk terjadinya risiko beserta dampaknya tanpa berusaha menghindari maupun meminimalisir. Biasanya hal ini dilakukan jika sudah tidak memungkinkan lagi untuk mengambil antisipasi. Apapun rencana dan implementasi yang Anda lakukan, tentunya tetap harus memperhatikan dampak terhadap keseluruhan proyek.

\section{Obyek Penelitian}

Obyek penelitian yaitu suatu atribut, sifat, atau nilai dari orang, obyek atau kegiatan yang mempunyai variasi tertentu yang ditetapkan oleh peneliti untuk dipelajari dan ditarik kesimpulannya (Sugiyono, 2019) [7]. Obyek penelitian dalam penelitian ini yaitu faktor-faktor yang mempengaruhi kegagalan pada implementasi proyek teknologi informasi dalam masa pandemi Covid-19.

\section{E. Jenis Penelitian}

Penelitian merupakan cara ilmiah untuk mendapatkan data dengan tujuan dan kegunaan tertentu [7]. Jenis penelitian yang digunakan ini adalah explanatory. Penelitian explanatory adalah penelitian yang bertujuan menelaah kualitas antar variabel yang menjelaskan suatu fenomena.

Variabel penelitian adalah segala sesuatu yang berbentuk apa saja yang merupakan suatu atribut atau sifat atau nilai dari orang, obyek atau kegiatan yang mempunyai variasi tertentu yang ditetapkan oleh peneliti untuk dipelajari dan ditarik kesimpulannya[7].

Melalui penelitian, kita dapat menggunakan hasilnya. Secara umum data yang diperoleh dari penelitian dapat digunakan untuk memahami, memecahkan, dan mengantisipasi masalah[7] yaitu faktor-faktor yang mempengaruhi kegagalan implementasi proyek teknologi informasi dalam masa pandemi Covid-19.

\section{F. Populasi dan Sampel}

Populasi adalah wilayah generalisasi yang terdiri atas obyek/subyek yang mempunyai kualitas dan karakteristik tertentu yang ditetapkan oleh peneliti untuk dipelajari dan kemudian ditarik kesimpulannya[7]. Populasi dalam penelitian ini adalah perusahaan teknologi informasi yang masih menjalankan bisnisnya di kota Bandung dan Jakarta.

Sampel adalah bagian dari jumlah dan karakteristik yang dimiliki oleh populasi tersebut apa yang dipeljari dari sampel, kesimpulannya akan dapat diberlakukan untuk populasi. Oleh karena itu, sampel yang diambil dari polulasi harus representatif atau mewakili[7]. Dalam penelitian ini, teknik penarikan sampel yang digunakan adalah nonprobability sampling, yaitu teknik pengambilan sampel yang tidak memberi peluang / kesempatan sama bagi setiap unsur atau anggota populasi untuk dipilih menjadi sampel [7]. 


\section{G. Jenis dan Sumber Data Penelitian}

Teknik yang dilakukan dalam nonprobability sampling adalah dengan menggunakan teknik incidental sampling, yaitu teknik penentuan sampel berdasarkan faktor spontanitas atau kebetulan. Dalam hal ini siapa saja yang secara kebetulan bertemu dengan peneliti dan sesuai dengan karakteristiknya dapat digunakan sebagai sampel, jika dipandang orang yang kebetulan ditemui itu cocok sebagai sumber data [7].

Paling sedikit harus ada 4 atau 5 kali dari jumlah pertanyaan dan dalam penelitian ini ada 34 item pertanyaan. Jadi, jumlah sampel yang diambil adalah 136 sampai 170 sampel. Data yang digunakan pada penelitian ini adalah kuantitatif, yaitu jenis data yang dapat diukur stau dihitung langsung, yang berupa informasi atau penjelasan yang dinyatakan dalam bentuk bilangan atau angka [7].

Sumber data yang digunakan dalam penelitian ini adalah data primer, yaitu data yang dikumpulkan dan diolah sendiri oleh suatau organisasi atau perorangan langsung dari obyeknya. Pengumpulan data tersebut dilakukan secara khusus untuk mengatasi masalah yang sedang diteliti.

\section{H. Teknik Pengumpulan Data}

Dalam pengumpulan data primer, penelitian ini menggunakan metode survey dengan menggunakan kuesioner yang disebarkan kepada karyawan yang terlibat proyek pada perusahaan yang tersebut pada sampel. Kuesioner merupakan teknik pengumpulan data yang dilakukan dengan memberi seperangkat pertanyaan atau pernyataan tertulis kepada responden untuk dijawabnya. seduai dengan permintaan pengguna [6].

Pengisian kuesioner menggunakan skala Likert, yaitu skala kuesioner didesain untuk menelaah seberapa kuat obyek setuju atau tidak setuju dengan pertanyaan pada skala 5 titik (Sekaran, 2003). Adapun susunannya adalah sebagai berikut : 1 = Sangat Tidak Setuju (STS), $2=$ Tidak Setuju (TS), 3 = Cukup Setuju (CS), 4 = Setuju (S), 5 = Sangat Setuju (SS).

\section{Uji Instrumen}

Setelah populasi dan sampel penelitian ditetapkan oleh peneliti, maka langkah selanjutnya peneliti mengumpulkan data dari obyek tersebut. Untuk dapat mengumpulkan data dengan teliti, maka peneliti perlu menggunakan instrumen penelitian (alat ukur). Instrumen yang baik adalah instrumen yang valid dan reliabel. Dalam suatau penelitian, data mempunyai kedudukan yang sangat penting. Dengan instrumen yang valid dan reliabel ini diharapkan akan diperoleh data yang valid dan reliabel pula. Valid atau tidaknya data sangat menentukan kualitas dari data tersebut. Hal ini tergantung instrumen yang digunakan, apakah sudah memenuhi asas validitas dan reliabilitas [7].

Instrumen yang diperlukan yaitu untuk mengungkapkan faktor-faktor yang mempengaruhi kegagalan implementasi proyek teknologi informasi dalam masa pandemi Covid-19. Sumber datanya adalah para karyawan yang terlibat pada tim proyek teknologi informasi tersebut. Bentuk instrumennya adalah checklist yaitu suatu daftar yang berisi subyek dari aspek-aspek yang diamati. Untuk itu dapat digunakan sebagai pedoman observasi, wawancara, maupun kuesioner [6].

\section{J. Metode Analisis Data}

Dari pengumpulan data yang menggunakan skala Likert, kemudian dilakukan penyajian data. Setiap peneliti harus dapat menyajikan data yang telah diperoleh melalui kuesioner. Prinsip dasar penyajian data adalah komunikatif dan lengkap, dalam arti data yang disajikan dapat menarik perhatian pihak lain untuk membacanya dan mudah memahami isinya [7]. Penyajian data yang komunikatif tersebut akan dilakukan dengan cara sebagai berikut :

a. Pembuatan tabel untuk melakukan penjumlahan terhadap setiap skala Likert, berapa orang yang memberikan Sangat Tidak Setuju (STS), Tidak Setuju (TS), Cukup Setuju (CS), Setuju (S), dan Sangat Setuju (SS).

b. Mengurutkan faktor-faktor yang mempengaruhi kegagalan implementasi proyek teknologi informasi dalam masa pandemi Covid-19, yang akan digambarkan dengan grafik distribusi frekuensi, yaitu penyusunan suatu data mulai dari terkecil sampai terbesar, atau sebaliknya yang membagi banyaknya data ke dalam beberapa kelas [6].

c. Melakukan pengukuran gejala pusat (central tendency), yang terdiri dari modus, median, dan mean, yang merupakan teknik statistik yang digunakan untuk menjelaskan kelompok, yang didasarkan atas gelaja pusat (central tendency) dari kelompok tersebut[7].

d. Modus merupakan teknik penjelasan kelompok yang didasarkan atas nilai yang sednag popular (yang sedang menjadi mode) atau nilai yang sering muncul dalam kelompok tersebut. Median adalah salah satu teknik penjelasan kelompok yang didasarkan atas nilai tengah dari kelompok data yang telah disusun urutannya dari yang terkecil sampai yang terbesar, atau sebaliknya. Mean merupakan teknik penjelasan kelompok yang diasarkan atas nilai rata-rata dari kelompok tersebut[7].

\section{HASIL DAN PEMBAHASAN}

1. Sistem atau Metodologi Manajemen Proyek

Belum adanya solusi formal untuk sistem atau metodologi manajemen proyek (TS dan S).

a. Belum memahami nilai dari manajemen proyek (TS).

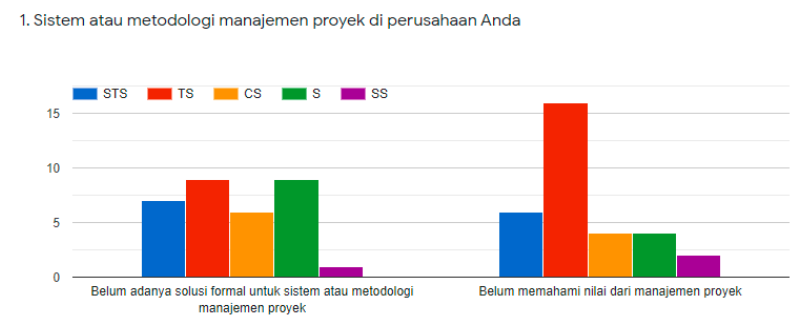

Gambar 1 : Grafik pemahaman nilai manajemen proyek

2. Project Management Office (PMO)

a. Belum menggunakan praktek manajemen proyek yang sudah terstandarisasi (TS) 
b. Belum bisa menetapkan atau memonitor ukuran kinerja keberhasilan proyek (CS)

c. Belum bisa melakukan manajemen alokasi sumber daya proyek, penyusunan anggota tim proyek yang tidak tepat, termasuk untuk menyediakan manajer proyek (TS)

Ganbar 2 : Grafik Project Management Office (PMO)

3. Masalah yang terkait dengan kontribusi anggota tim proyek
a. Kurangnya keselarasan dengan tim (TS)
b. Kurangnya keterbukaan dalam komunikasi (CS)
c. Ketidakmampuan untuk menyelesaikan konflik (TS)
d. Kurangnya partisipasi dan kreativitas tim (S)
e. Kepemimpinan yang tidak efektif, dalam hal ini manajer proyek yang tidak berpengalaman (TS)
f. Kurangnya penghargaan pada anggota tim proyek (S)

Gambar 4 : Grafik alat kerja ootomatis

5. Keterlibatan pemangku kepentingan (stakeholder)

a. Kurangnya dukungan dari manajemen dan sponsor yang secara aktif mendukung pelaksanaan proyek (S)

b. Belum menciptakan budaya yang menghargai manajemen proyek $(\mathrm{S})$

c. Belum mengembangkan keterampilan implementasi strategi di kalangan pemangku kepentingan (S)

Gambar 5 : Grafik keterlibatan pemangku kepentingan

6. Permintaan kebutuhan yang tidak direncanakan (ad hoc requests).

a. Kebutuhan proyek yang tidak jelas dan sering mengalami perubahan yang tidak direncanakan (S)

Gambar 6 : Grafik kebutuhan proyek yang tidak jelas

Gambar 3 : Grafik kontribusi tim proyek

4. Alur kerja otomatis untuk solusi manajemen proyek modern

a. Belum adanya solusi formal untuk alur kerja otomatis (S)

b. Belum memahami transformasi digital yang telah berkembang pesat sampai saat ini (TS) 
c. Kurangnya niat untuk belajar dari kegagalan proyek sebelumnya (TS)

Gambar 7 : Grafik tingkat kematangan proyek

8. Investasi untuk memperluas keterampilan dalam manajemen proyek
a. Belum melakukan pelatihan tentang penggunaan alat dan teknik manajemen proyek (S)
b. Belum memiliki proses formal untuk mengembangkan kompetensi manajer proyek (S)
c. Belum memiliki jalur karir yang ditentukan untuk mereka yang terlibat dalam manajemen proyek (S)
d. Belum memiliki proses formal untuk mentransfer pengetahuan dari satu bagian organisasi ke bagian lainnya (CS)
e. Kurang memprioritaskan pengembangan keterampilan teknis , profesional, kepemimpinan, dan bisnis manajemen proyek (TS)

Ganbar 8 : Grafik investasi ktrampilan manajemen proyek 9. Manajemen risiko proyek
a. Belum menerapkan manajemen risiko proyek, peluang dan risiko tidak ditentukan (S)
b. Kurangnya ketersedian sumber daya proyek atau keterbatasan sumber daya proyek (S)

Gambar 9 : Grafik manajemen risiko proyek

10. Manajemen perubahan proyek

a. Belum menerapkan manajemen perubahan proyek atau manajemen perubahan yang buruk (S)

b. Adanya perubahan dalam prioritas perusahaan dan tujuan proyek, belum menciptakan budaya reseptif terhadap perubahan organisasi (CS)

c. Adanya perubahan yang tidak terkontrol pada ruang lingkup proyek (TS dan S)

Gambar 10 : Grafik manajemen perubahan proyek

\section{KESIMPULAN}

Berdasarkan hasil pengolahan data dari pengisian kuesioner oleh responden, maka dapat disimpulkan bahwa responden yang mengisi kuesioner paling banyak bergerak di bidang Teknologi Informasi (43\%).

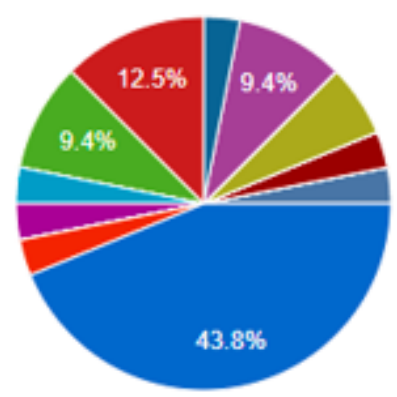

Gambar 11 : Grafik profil responden

Dari hasil penelitian, maka dapat disimpulkan bahwa responden setuju (S) terhadap faktor-faktor yang mempengaruhi kegagalan implementasi proyek yaitu :

1. Sistem atau metodologi manajemen proyek di perusahaan

2. Alur kerja otomatis untuk solusi manajemen proyek modern.

3. Keterlibatan pemangku kepentingan (stakeholder).

4. Permintaan kebutuhan yang tidak direncanakan (ad hoc 
requests).

5. Tingkat kematangan yang mengarah ke kinerja proyek yang lebih besar.

6. Investasi untuk memperluas keterampilan dalam manajemen proyek.

7. Manajemen risiko proyek.

8. Manajemen perubahan proyek.

\section{UCAPAN TERIMA KASIH}

Kami mengucapkan terima kasih kepada semua responden yang telah mengisi kuesioner penelitian ini sehingga peneliti bisa memberikan jawaban terhadap "Tantangan implementasi manajemen proyek Teknologi Informasi dalam masa pandemi covid 19". Juga terima kasih kepada Ketua (Dr. Abdurrahman, M.T.), para dosen STMIK Bandung terutama kepada Ibu Siti Yuliyanti, S.T., M.Kom., Sdr. Kafi Rohman Syahid, dan Bapak Moch. Rizki Romdoni, S.Kom. M.T. dari STTI Tanjungpinang, serta keluarga yang telah mendukung aktivitas penelitian ini.

\section{REFERENSI}

[1] Chan, KC, Peter Ong and R. Eko Indrajit. 2004, Integrated Project Management, Yogyakarta, Indonesia, Penerbit Andi.

[2] Heryanto, Imam dan Totok Triwibowo, 2016, Manajemen Proyek Berbasis Teknologi Informasi, Bandung, Indonesia, Penerbit Informatika.

[3] Husen, Abrar, 2011, Manajemen Proyek-Perencanaan, Penjadwalan, dan Pengendalian Proyek, Yogyakarta, Indonesia, Penerbit Andi.

[4] Orr, Alan D., 2004, Advanced Project Management, London, UK, Kogan Page.

[5] Project Management Institue, 2017, A Guide to the Project Management Body of Knowledge 6th Edition, Pennsilvania, USA, Project Management Institue, Inc.

[6] Sugiyono, 2018, Metode Penelitian Kuantitatif, Kualitatif, dan $R \& D$, Bandung, Indonesia, Alfabeta.

[7] Sugiyono, 2019, Statistika untuk Penelitian, Bandung, Indonesia, Alfabeta.

[8] Tantra, Rudy, 2012, Manajemen Proyek Sistem Informasi, Yogyakarta, Indonesia, Penerbit Andi. 